\title{
IL-22 produced by cancer-associated fibroblasts promotes gastric cancer cell invasion via STAT3 and ERK signaling
}

\author{
H Fukui ${ }^{\star, 1}$, X Zhang ${ }^{1,2,6}$, C Sun ${ }^{1,3,6}$, K Hara $^{1}$, S Kikuchi ${ }^{4}$, T Yamasaki ${ }^{1}$, T Kondo ${ }^{1}$, T Tomita ${ }^{1}$, T Oshima ${ }^{1}$, \\ J Watari ${ }^{1}$, J Imura ${ }^{5}$, T Fujimori ${ }^{5}$, M Sasako ${ }^{4}$ and H Miwa ${ }^{1}$ \\ ${ }^{1}$ Division of Gastroenterology, Department of Internal Medicine, Hyogo College of Medicine, Nishinomiya 663-8501, Japan; \\ ${ }^{2}$ Department of Geriatric Digestive Internal Medicine, Sichuan Academy of Medical Science \& Sichuan People's Hospital, \\ Chengdu 610072, China; ${ }^{3}$ Department of Digestive Diseases, Tianjin Medical University General Hospital, Tianjin 300052, China; \\ ${ }^{4}$ Department of Surgery, Hyogo College of Medicine, Nishinomiya 663-8501, Japan and ${ }^{5}$ Department of Surgical and Molecular \\ Pathology, Dokkyo University School of Medicine, Tochigi 321-0293, Japan
}

Background: Interleukin-22 (IL-22) has been recently highlighted owing to its biological significance in the modulation of tissue responses during inflammation. However, the role of IL-22 in carcinogenesis has remained unclear. Here, we investigated the pathophysiological significance of IL-22 expression in gastric cancer tissues and examined the mechanism by which IL-22 promotes gastric cancer cell invasion.

Methods: Human gastric cancer specimens were analysed by immunohistochemistry for expression of IL-22 and IL-22 receptor 1 (IL-22R1). The effects of IL-22-induced STAT3 and ERK signalling on invasive ability of gastric cancer cells were examined using a small-interfering RNA system and specific inhibitors. AGS cells were co-cultured with cancer-associated fibroblasts (CAFs) from human gastric cancer tissues and assessed by invasion assay.

Results: Interleukin-22 and its receptor were expressed in $\alpha$-smooth muscle actin-positive stromal cells and tumour cells at the invasive front of gastric cancer tissues, respectively. The expression of IL-22 and IL-22R1 was significantly related to lymphatic invasion. Interleukin-22 treatment promoted the invasive ability of gastric cancer cells through STAT3 and ERK activation. The invasive ability of gastric cancer cells was significantly enhanced by co-culture with IL-22-expressing CAFs.

Conclusions: Interleukin-22 produced by CAFs promotes gastric cancer cell invasion via STAT3 and ERK signalling.

Gastric cancer, the second leading cause of cancer-related death worldwide (Kamangar et al, 2006), is known to have a poor prognosis due to its marked propensity for invasion and metastasis. Recently, accumulating evidence has suggested that cross-talk between cancer cells and their surrounding stromal cells has a pivotal role in invasion and metastasis during tumour progression (Bhowmick et al, 2004; Xing et al, 2010). Indeed, gastric cancer tissues consist of not only cancerous cells but also stromal cells including fibroblasts, immune cells and endothelial cells, and those cells are likely to communicate via cytokines, chemokines, growth factors or extracellular matrix (Cirri and Chiarugi, 2012).

Interleukin-22 (IL-22) is a recently identified IL-10 superfamily cytokine produced mainly by activated lymphocytes in chronically inflamed tissues (Dumoutier et al, 2000a; Liang et al, 2006; Zheng et al, 2007), and its receptor consists of two chains: IL-22 receptor 1 (IL-22R1) and IL-10 receptor 2 (IL-10R2) (Xie et al, 2000; Dumoutier et al, 2000b). Interestingly, IL-10R2 is expressed ubiquitously in various organs, whereas expression of IL-22R1 is

\footnotetext{
*Correspondence: Dr H Fukui; E-mail: hfukui@hyo-med.ac.jp

${ }^{6}$ These authors contributed equally to this work
}

Received 10 February 2014; revised 17 May 2014; accepted 20 May 2014; published online 17 June 2014

(c) 2014 Cancer Research UK. All rights reserved 0007-0920/14 
restricted to epithelial cells, and not immune cells, in the skin, pancreas, kidney, liver, and gastrointestinal tract (Aggarwal et al, 2001; Wolk et al, 2004). In this regard, IL-22 may have pivotal roles as a biological mediator in signalling from the immune system to epithelial cells in the gastric mucosa. Detailed studies of the biological roles of IL-22 have suggested that IL-22 is likely to exert multiple functions under inflammatory conditions because its signalling modulates the expression of many genes involved in chemotaxis, proliferation, innate immunity and inflammation (Zenewicz and Flavell, 2011; Rutz et al, 2013). On the other hand, the role of IL-22 in carcinogenesis remains somewhat unclear, even though chronic inflammation is a process involved in the development of various cancers. At the beginning of this study, we examined the expression of IL-22 in gastric cancer tissues and found that IL-22-positive stromal cells were increased at the invasive tumour front. Therefore, in the present study, we investigated whether IL-22 has a role in gastric cancer cell invasion and examined in vitro the process of intracellular signalling by which IL-22 promotes gastric cancer cell invasion. Moreover, we examined whether gastric cancer-associated fibroblasts (CAFs) are a possible source of IL-22 and whether they are associated with the promotion of gastric cancer cell invasion.

\section{MATERIALS AND METHODS}

Reagents and cell culture. Human recombinant IL-22 protein, anti-human IL-10R2 antibody and anti-human IL-22 neutralising antibody were purchased from R\&D Systems (Minneapolis, MN, USA). MEK inhibitor PD98059 and PI3K-Akt inhibitor wortmannin were from Sigma (St Louis, MO, USA). Anti-STAT3, anti-phosphospecific STAT3 (p-STAT3; Tyr705), anti-Akt, anti-phospho-specific Akt (p-Akt; Ser473), anti-ERK, and anti-phospho-specific ERK (p-ERK) antibodies were purchased from Cell Signaling Technology (Beverly, MA, USA). Anti- $\beta$-actin antibody was purchased from Sigma.

The gastric cancer cell lines MKN1, MKN28, MKN45, MKN74, and GCIY were maintained in RPMI 1640 medium (Invitrogen, Grand Island, NY, USA) with 10\% fetal bovine serum (Invitrogen) in a humidified incubator at $37^{\circ} \mathrm{C}$ with an atmosphere of $5 \% \mathrm{CO}_{2}$. Similarly, KATOIII cells were cultured in RPMI 1640 medium with $20 \%$ fetal bovine serum, and AGS cells were maintained in Ham's F12 medium (ICN Biomedical, Aurora, OH, USA) with 10\% fetal bovine serum.

Tissue specimens and histological examination. A total of 36 gastric cancers tissues were obtained from specimens resected surgically at Dokkyo University School of Medicine. The tissue specimens were fixed in $10 \%$ formalin solution and embedded in paraffin. This study was approved by the Dokkyo University Surgical Pathology Committee, and informed consent was obtained from all patients.

Multiple hematoxylin-eosin-stained sections of all 36 lesions were examined (Supplementary Table 1). The following factors were determined for all patients and lesions; age, sex, tumour size, tumour location, Lauren's histological classification, tumour invasion, lymph node metastases, and tumour stage according to the American Joint Committee on Cancer system.

Immunohistochemistry. Immunohistochemical staining for IL-22, IL-22R1, and phosphorylated STAT3 (p-STAT3) was performed with an Envision kit (DAKO, Kyoto, Japan) or an LSAB2 kit as described previously (Sekikawa et al, 2008, 2010; Fukui et al, 2011), using anti-IL-22 antibody (1:200; Santa Cruz Biotechnology, Santa Cruz, CA, USA), anti-IL-22R1 antibody (1:25; Abcam, Cambridge, UK), and anti-p-STAT3 antibody (1:15; Cell Signaling Technology). Finally, the sections were incubated in $3,3^{\prime}$-diaminobenzide tetrahydrochloride with $0.05 \%$
$\mathrm{H}_{2} \mathrm{O}_{2}$ for 3 min and then counterstained with Mayer's hematoxylin. To evaluate the immunoreactivity of IL-22, at least five different visual fields were observed at the invasive front of gastric cancer lesions. A specimen was considered positive when IL-22positive fibroblastic nests were observed in the visual fields examined. IL-22R1 was focally expressed at the invasive front or diffusely at whole parts of gastric cancer lesion. Both of the immunostaining patterns were considered as positive, whereas no immunoreactivity was considered as negative. Immunoreactivity of p-STAT3 was evaluated as previously described (Sekikawa et al, 2008). A specimen was considered positive when $>10 \%$ of the tumour cell nuclei were positively stained.

Immunohistochemical double staining was performed in gastric cancer tissues as previously described (Sekikawa et al, 2010). In brief, the sections were incubated with goat anti-IL-22 antibody $(1: 50)$ or mouse anti- $\alpha$ smooth muscle actin ( $\alpha$ SMA) for $60 \mathrm{~min}$ at room temperature. Then, the sections were incubated with fluorescein isothiocyanate-conjugated anti-goat immunoglobulin (1:100; Dako) and Alexa Fluor 546 (1:100; Invitrogen) for $30 \mathrm{~min}$ at room temperature. After washing in phosphate-buffered saline (PBS), the sections were observed by confocal laser microscopy (LSM510; Carl Zeiss Japan, Tokyo, Japan).

RNA extraction and RT-PCR. Total RNA was extracted from each cell line using Trizol reagent (Invitrogen). Five micrograms of total RNA was reverse-transcribed using oligo dT primer (Applied Biosystems, Branchburg, NJ, USA) and $200 \mathrm{U}$ of Superscript II reverse transcriptase (Invitrogen) in a total volume of $20 \mu \mathrm{l}$. For the following PCR, pairs of oligonucleotide primers for human IL-22 (Ziesché et al, 2009), human IL-22R1 (Naher et al, 2012), human IL-10R2 (Naher et al, 2012), and human glyceraldehyde-3phosphate dehydrogenase (GAPDH; Ogata et al, 2010) were prepared. Human IL-22: 5'-GCTAAGGAGGCTAGCTTG-3' (sense) and 5'-CAGCAAATCCAGTTCTCC-3' (antisense); human IL-22R1: 5'-CTCCACAGCGGCATAGCCT-3' (sense) and 5'-ACATGCAGCTTCCAGCTGG-3' (antisense); human IL-10R2: $5^{\prime}$-GGCTGAATTTGCAGATGAGCA-3' (sense) and $5^{\prime}$-GAAG ACCGAGGCCATGAGG-3' (antisense); human GAPDH: $5^{\prime}$-GGC TGCTTTTAACTCTGGTA-3' (sense) and 5'-ATGCCAGTGA GCTTCCCGT-3' (antisense). One microliter of RT product (cDNA) was amplified by PCR in a $50-\mu$ l reaction volume containing $20 \mathrm{pmol}$ of the above sets of primers, $1.25 \mathrm{U}$ of AmpliTaq DNA polymerase (Applied Biosystems, Foster City, CA, USA), and the final PCR buffer: $20 \mathrm{~mm}$ Tris- $\mathrm{HCl}(\mathrm{pH} 8.4), 50 \mathrm{~mm} \mathrm{KCl}$, $2.5 \mathrm{mM} \mathrm{MgCl}_{2}, 10 \mathrm{~mm}$ dithiothreitol, and $1 \mathrm{~mm}$ dNTP. The PCR amplification was performed as follows: at $95^{\circ} \mathrm{C}$ for 5 min once; 35 cycles at $95^{\circ} \mathrm{C}$ for $1 \mathrm{~min}$, at $60^{\circ} \mathrm{C}$ for $1 \mathrm{~min}$, and at $72^{\circ} \mathrm{C}$ for $1 \mathrm{~min}$; then at $72{ }^{\circ} \mathrm{C}$ for $7 \mathrm{~min}$.

Real-time RT-PCR. Real-time reverse transcription-polymerase chain reaction (RT-PCR) was performed using 7900H Fast RealTime PCR System (Applied Biosystems) as previously described (Sekikawa et al, 2010). The following sets of primers for human matrix metalloproteinase 7 (MMP7), MMP13, IL-22, IL-22R1, and $G A P D H$, were prepared (Supplementary Table 2). Real-time RT-PCR assays were carried out with $200 \mathrm{ng}$ RNA equivalent cDNA, SYBR Green Master Mix (Applied Biosystems), and $500 \mathrm{nmoll}^{-1}$ gene-specific primers. The PCR cycling conditions were $50{ }^{\circ} \mathrm{C}$ for $15 \mathrm{~s}$ and $60{ }^{\circ} \mathrm{C}$ for $60 \mathrm{~s}$. The intensity of the fluorescent dye was determined, and each of mRNA expression levels was normalised to GAPDH mRNA expression levels.

Western blot analysis. Proteins were extracted as previously reported (Hoshino et al, 2007). In brief, following treatment with or without reagents, cells were lysed in protein extraction buffer. Proteins from membrane and cytoplasm were extracted from the supernatants and the precipitation was additionally treated with 
nuclear lysis buffer. After centrifugation, nuclear protein was extracted from the treated supernatants.

Western blot analyses were performed using each primary antibody as previously described (Sekikawa et al, 2008). Protein extract $(25 \mu \mathrm{g})$ was fractionated by sodium dodecyl sulphate polyacrylamide gel electrophoresis and transferred to a polyvinylidene difluoride membrane. The membrane was incubated with a primary antibody and then with a peroxidase-conjugated secondary antibody. Proteins were detected using an enhanced chemiluminescence system (Amersham Biosciences, Buckinghamshire, UK).

RNA interference. Small-interfering RNA for human STAT3 (STAT3 siRNA) was obtained from Qiagen (Hilden, Germany). AGS and MKN28 cells were seeded in 6-cm dish (Iwaki, Funabashi, Japan) and maintained for $24 \mathrm{~h}$. Then, the cells were transfected with $25 \mathrm{~nm}$ STAT3 siRNA or non-silencing siRNA (as a control) using the Oligofectamine reagent (Qiagen) according to the manufacturer's recommendation (Sekikawa et al, 2010). After incubation for $48 \mathrm{~h}$, cells were washed with PBS, harvested, and subjected to invasion assay.

Invasion assay. Cell invasion assay was performed using BioCoat Matrigel invasion chambers (BD Biosciences, Bedford, MA, USA) in accordance with the manufacturer's protocol. Briefly, AGS $\left(5 \times 10^{4}\right)$, MKN28 $\left(5 \times 10^{5}\right)$, or those with RNA interference treatment were seeded in the upper matrigel-coated invasion chamber ( 24 wells, $8-\mu \mathrm{m}$ pore size), and the lower chamber was filled with serum-free medium containing different concentrations of IL-22 $\left(0-100 \mathrm{ng} \mathrm{ml}^{-1}\right)$. To inhibit the effects of IL-22 $\left(10 \mathrm{ng} \mathrm{ml}^{-1}\right)$ or its related ERK signalling, anti-IL-22 antibody $\left(0-40 \mu \mathrm{g} \mathrm{ml}^{-1}\right)$ or MEK inhibitor PD98059 $(20 \mu \mathrm{M})$ was added to the upper chamber. After incubation for $36 \mathrm{~h}$, non-invading cells were removed using a cotton swab and the cells that had invaded into the lower surface of the membrane were fixed with $10 \%$ buffered formalin. The invading cells were then stained with hematoxylin and counted using a microscope in five different visual fields (magnification, $\times 200$ ).

Isolation of CAFs and ELISA. Human gastric cancer specimens were obtained from patients who underwent gastrectomy at Hyogo College of Medicine Hospital in 2012. Tissue specimens were prepared from the cancerous portion (CAFs) and non-cancerous portion at least $50 \mathrm{~mm}$ distant from the tumour (normal gastric fibroblasts; NGFs) in the stomach. The tissue specimens were trimmed of fat and necrotic tissue, minced with scalpels and washed in PBS containing antibiotic-antimycotic reagent (AntiAnti, GIBCO, Grand Island, NY, USA). The tissue pieces were transferred to a 12-well microplate (IWAKI, Tokyo, Japan) at one fragment per well. The cells were cultured in DMEM medium (GIBCO) with 10\% heat-inactivated FCS (Biowest, Nuaillé, France) at $37{ }^{\circ} \mathrm{C}$ in an atmosphere of $5 \% \mathrm{CO}_{2}$. The fibroblasts that initially grew in a monolayer were collected, transferred to another dish and used for experiments within the 10th passage.
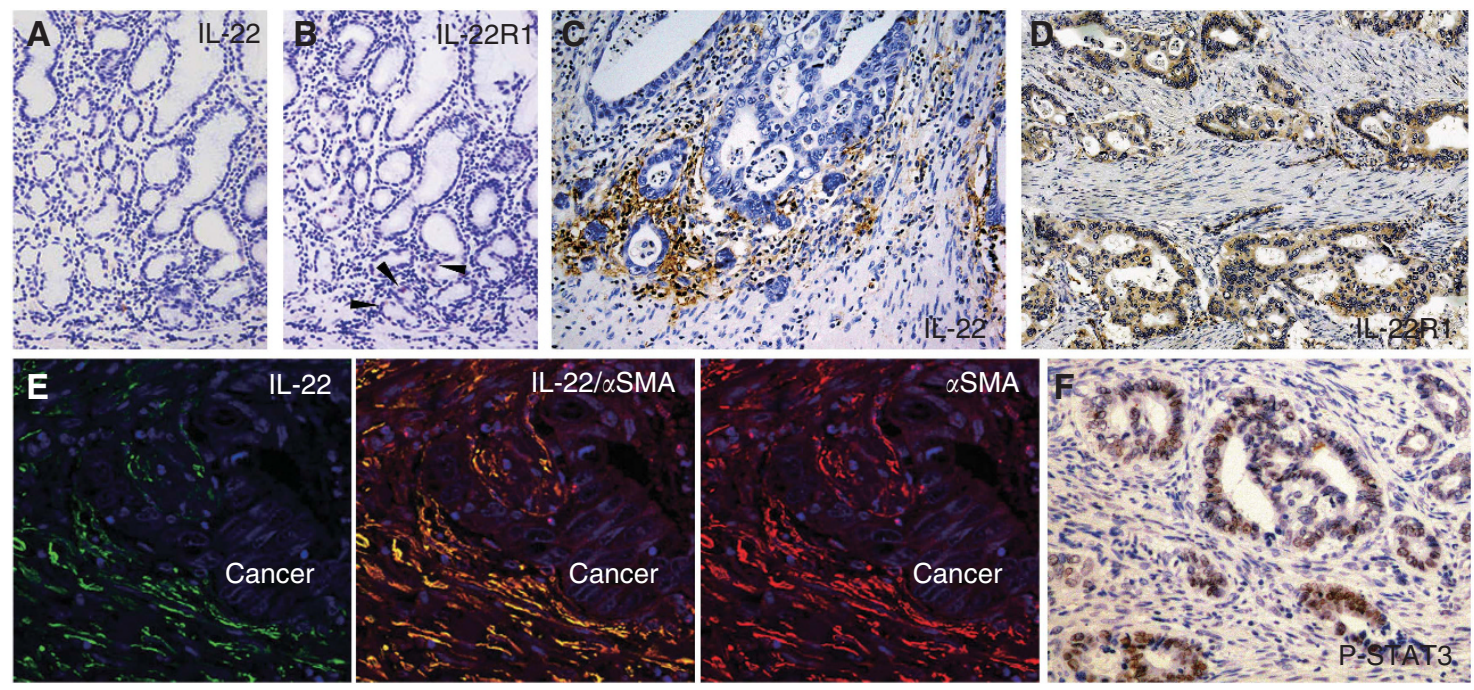

G
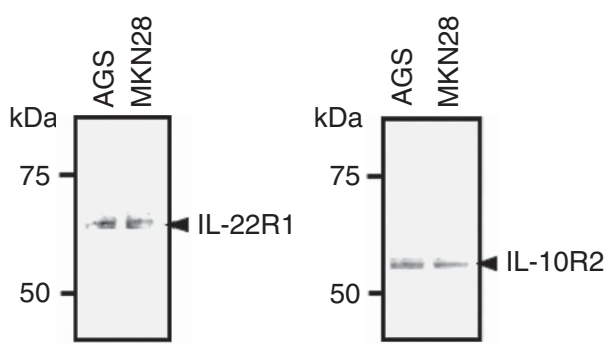

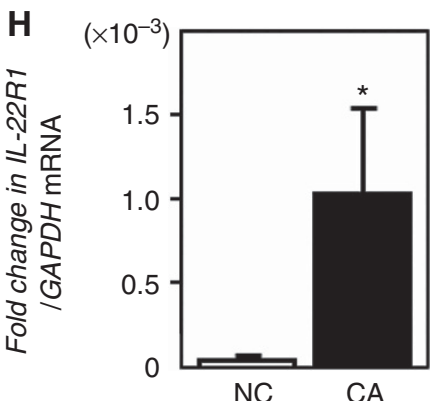

Figure 1. Immunohistochemical localisation of IL-22 and IL-22R1 in normal gastric (A and B) and gastric cancer tissues (C and D). (E) Double immunostaining of IL-22 (green in left panel) and $\alpha \mathrm{SMA}$ (red in right panel) at the invasive front of a gastric cancer lesion. The section was counterstained with DAPI (blue signal). IL-22 is co-expressed in the $\alpha$ SMA-positive stromal cells (yellow in the middle panel). (F) Immunoreactivity of p-STAT3 in the nuclei of invasive gastric cancer cells. (G) Detection of IL-22R1 and IL-10R2 protein expression in gastric cancer cells by western blotting. (H) Expression of IL-22R1 in surgically resected gastric cancers (CA; $n=4)$ and normal gastric mucosa biopsied from controls without cancers $(\mathrm{NC} ; n=8)$. All the results are presented as the mean \pm s.e.m. Significantly greater than $\mathrm{NC}$ group: ${ }^{\star} P<0.05$. Abbreviation: $\mathrm{DAPI}$ 4',6-diamidino-2-phenylindole. 
Serum samples were obtained from healthy volunteers and patients with ulcerative colitis (UC) at Hyogo College of Medicine Hospital. On the other hand, CAF cells were cultured on 6-well dishes in DMEM medium with $10 \%$ heat-inactivated FCS. When the cells reached $50-70 \%$ confluence, the cells were washed with PBS, and the medium was replaced with serum-free DMEM medium. Forty-eight hour later, the culture supernatant was collected. Human IL-22 was quantified by ELISA (R\&D Systems) according to the manufacturer's recommendation. These studies were done with the approval of the Review Board of Hyogo College of Medicine, and informed consent was obtained from all patients.

Statistical analysis. All values were expressed as the mean \pm s.e.m. The data for cell invasion were analysed using unpaired two-tailed $t$-test. Chi-squared analyses were performed to determine the correlation between various pathological parameters, and Fisher's exact test was also performed when necessary. $P$-values less than 0.05 were considered to indicate statistical significance.

\section{RESULTS}

Immunohistochemical localisation of IL-22, IL-22R1, and p-STAT3 expression in gastric cancer tissues. In normal gastric mucosa, immunoreactivity for IL-22 was hardly detectable, even in lymphocytes (Figure 1A). Weak immunoreactivity for IL-22R1 was observed in a few epithelial cells in the basal portion of gastric glands (Figure 1B, arrowheads).

In gastric cancerous tissues, immunoreactivity for IL-22 was observed mainly in spindle or fibrous stromal cells at the invasive front of the tumour (Figure 1C), and IL-22R1 was expressed in the plasma membrane and cytoplasm of gastric cancer cells (Figure 1D). Double immunostaining showed that IL-22 was coexpressed in aSMA-positive stromal cells at the invasive front, suggesting that CAF cells may produce IL-22 (Figure 1E). In addition, p-STAT3 was strongly expressed in the nuclei of invasive gastric cancer cells (Figure 1F).

We next investigated the clinicopathological significance of IL-22 and IL-22R1 expression in patients with gastric cancer (Table 1). IL-22 expression was significantly associated with the prevalence of lymphatic invasion, lymph node metastasis and high tumour stage, but other parameters-age, gender, tumour location, Lauren's classification, and venous invasion-showed no significant relationship to IL-22 expression. IL-22R1 expression was also significantly associated with the prevalence of lymphatic invasion but not with other parameters. Of the 29 gastric cancers with IL-22-positivity, $28(96.6 \%)$ were positive for IL-22R1 expression, suggesting that IL-22R1 expression was positively related to IL-22 expression in the gastric cancer tissues investigated in the present study $(P<0.05)$. Moreover, we investigated the clinicopathological significance of p-STAT3 expression in the available 31 gastric cancer tissues. Expression of p-STAT3 was significantly associated with the prevalence of lymph node metastasis and tempting to be related to tumour stage and lymphatic or venous invasion (Table 2). In addition, p-STAT3 expression was significantly correlated with IL-22 expression in gastric cancer tissues.

Before examining the effect of IL-22 on gastric cancer cells, we screened the expression of the $I L-22$ receptors, $I L-22 R 1$ and $I L-10 R 2$, in seven gastric cancer cell lines using RT-PCR. As shown in Supplementary Figure 1, expression of the mRNA for both the $I L-22 R 1$ and $I L-10 R 2$ genes was detected in all seven gastric cancer cell lines examined. Furthermore, we showed that AGS and MKN28 cells express IL-22R1 and IL-10R2 protein (Figure 1G), suggesting that gastric cancer cells have the capability to respond to IL-22 stimulation. Moreover, the level of $I L-22 R 1$ expression was significantly greater in gastric cancer tissues than in normal gastric mucosa (Figure 1H).

IL-22 stimulation activates the phosphorylation of STAT3 and ERK in gastric cancer cells. We investigated the effect of IL-22

\begin{tabular}{|c|c|c|c|c|}
\hline & $\begin{array}{c}\text { Number of IL-22 } \\
\text { positive/total } \\
\text { number of patients }\end{array}$ & $P$-value & $\begin{array}{l}\text { Number of IL-22R1 } \\
\text { positive/total number } \\
\text { of patients }\end{array}$ & $P$-value \\
\hline Tumour location & & 0.8975 & & 0.4784 \\
\hline $\begin{array}{l}\text { Lower } \\
\text { Mid } \\
\text { Upper }\end{array}$ & $\begin{array}{r}7 / 9(77.8 \%) \\
11 / 13(84.6 \%) \\
11 / 14(78.6 \%)\end{array}$ & & $\begin{array}{r}9 / 9(100 \%) \\
12 / 13(92.3 \%) \\
12 / 14(85.7 \%)\end{array}$ & \\
\hline Lauren's classification & & 0.5515 & & $>0.9999$ \\
\hline $\begin{array}{l}\text { Intestinal type } \\
\text { Diffuse type }\end{array}$ & $\begin{array}{r}9 / 12(75.0 \%) \\
20 / 24(83.3 \%)\end{array}$ & & $\begin{array}{l}11 / 12(91.7 \%) \\
22 / 24(91.7 \%)\end{array}$ & \\
\hline Stage & & 0.0035 & & 0.3729 \\
\hline $\begin{array}{l}\text { I } \\
\text { II } \\
\text { III } \\
\text { IV }\end{array}$ & $\begin{array}{r}3 / 8(37.5 \%) \\
5 / 5(100 \%) \\
12 / 12(100 \%) \\
9 / 11(81.1 \%)\end{array}$ & & $\begin{array}{r}7 / 8(87.5 \%) \\
5 / 5(100 \%) \\
12 / 12(100 \%) \\
9 / 11(81.1 \%)\end{array}$ & \\
\hline Lymphatic invasion & & 0.0031 & & 0.0282 \\
\hline $\begin{array}{l}\text { None } \\
\text { Present }\end{array}$ & $\begin{array}{c}0 / 2(0.0 \%) \\
29 / 34(85.3 \%)\end{array}$ & & $\begin{array}{r}1 / 2(50.0 \%) \\
32 / 34(94.1 \%)\end{array}$ & \\
\hline Venous invasion & & 0.3464 & & 0.4185 \\
\hline $\begin{array}{l}\text { None } \\
\text { Present }\end{array}$ & $\begin{array}{r}4 / 6(66.7 \%) \\
25 / 30(83.3 \%)\end{array}$ & & $\begin{array}{r}5 / 6(83.3 \%) \\
28 / 30(93.3 \%)\end{array}$ & \\
\hline Lymph node metastasis & & 0.0016 & & 0.7277 \\
\hline $\begin{array}{l}\text { None } \\
\text { Present }\end{array}$ & $\begin{array}{r}4 / 9(44.4 \%) \\
25 / 27(92.6 \%)\end{array}$ & & $\begin{array}{r}8 / 9(88.9 \%) \\
25 / 27(92.6 \%)\end{array}$ & \\
\hline
\end{tabular}




\begin{tabular}{|c|c|c|c|}
\hline & \multicolumn{2}{|c|}{ p-STAT3 expression } & \multirow[b]{2}{*}{$P$-value } \\
\hline & Negative & Positive & \\
\hline Tumour location & & & 0.5642 \\
\hline $\begin{array}{l}\text { Lower } \\
\text { Mid } \\
\text { Upper }\end{array}$ & $\begin{array}{l}4 \\
4 \\
6\end{array}$ & $\begin{array}{l}4 \\
8 \\
5\end{array}$ & \\
\hline Lauren's classification & & & 0.9809 \\
\hline $\begin{array}{l}\text { Intestinal type } \\
\text { Diffuse type }\end{array}$ & $\begin{array}{l}5 \\
9\end{array}$ & $\begin{array}{r}6 \\
11\end{array}$ & \\
\hline Stage & & & 0.1102 \\
\hline $\begin{array}{l}\text { I } \\
\text { II } \\
\text { III } \\
\text { IV }\end{array}$ & $\begin{array}{l}5 \\
1 \\
6 \\
2\end{array}$ & $\begin{array}{l}2 \\
4 \\
4 \\
7\end{array}$ & \\
\hline Lymphatic invasion & & & 0.1071 \\
\hline $\begin{array}{l}\text { None } \\
\text { Present }\end{array}$ & $\begin{array}{r}2 \\
12\end{array}$ & $\begin{array}{r}0 \\
17\end{array}$ & \\
\hline Venous invasion & & & 0.0874 \\
\hline $\begin{array}{l}\text { None } \\
\text { Present }\end{array}$ & $\begin{array}{r}4 \\
10\end{array}$ & $\begin{array}{r}1 \\
16\end{array}$ & \\
\hline Lymph node metastasis & & & 0.0490 \\
\hline $\begin{array}{l}\text { None } \\
\text { Present }\end{array}$ & $\begin{array}{l}6 \\
8\end{array}$ & $\begin{array}{r}2 \\
15\end{array}$ & \\
\hline IL-22 expression & & & 0.0364 \\
\hline $\begin{array}{l}\text { Negative } \\
\text { Positive }\end{array}$ & $\begin{array}{l}5 \\
9\end{array}$ & $\begin{array}{r}1 \\
16\end{array}$ & \\
\hline IL-22R1 expression & & & 0.4310 \\
\hline $\begin{array}{l}\text { Negative } \\
\text { Positive }\end{array}$ & $\begin{array}{r}2 \\
12\end{array}$ & $\begin{array}{r}1 \\
16\end{array}$ & \\
\hline $\begin{array}{l}\text { Abbreviations: IL-22 =interle } \\
\text { indicated by bold entries. }\end{array}$ & $\mathrm{IL}-22 \mathrm{R} 1=\mathrm{IL}-22$ & eptor 1. P & es $<0.05$ ar \\
\hline
\end{tabular}

signalling on possible major pathways including STAT3, ERK, Akt and NF- $\kappa$ B in gastric cancer cell lines (Lejeune et al, 2002; Andoh et al, 2005; Zhang et al, 2008). The expression of p-STAT3 was strongly enhanced from $15 \mathrm{~min}$ after IL-22 stimulation in both AGS and MKN28 cells (Figure 2A). The expression of p-ERK was also enhanced in AGS and MKN28 cells. On the other hand, the effect of IL-22 stimulation on p-Akt expression was negligible in both cell types. With regard to NF- $\kappa$ B signalling, IL-22 stimulation affected neither nuclear p50 nor p60 expression in the two gastric cancer cell lines (Figure 2B). We moreover examined the effect of anti-IL-22 antibody on gastric cancer cells and confirmed that the increased phosphorylation of STAT3 and ERK by IL-22 stimulation was abolished by concomitant administration of anti-IL-22 antibody (Figure 2C).

Interleukin-22 stimulation promotes the invasive ability of gastric cancer cells. We pursued a function of IL-22 invasive ability of gastric cancer cells as IL-22-positive stromal cells were increased at the invasive tumour front. We examined the invasive ability of gastric cancer cells stimulated with IL-22 using a Matrigel invasion assay. Gastric cancer cells that had invaded across the membrane were observed below the membrane (Figure 3A). When AGS cells were stimulated with IL-22, the number of invasive cells was significantly increased in a dose-dependent manner (Figure 3A). Similarly, the invasive ability of MKN28 cells was
A

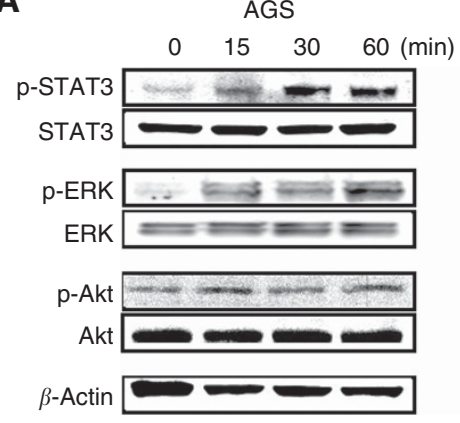

B
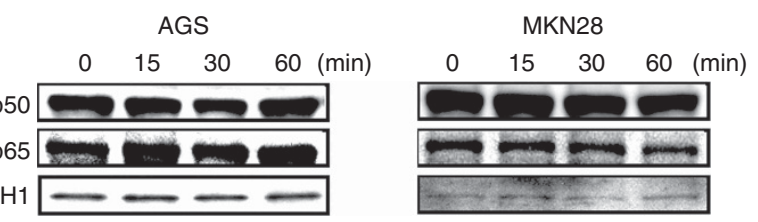

C
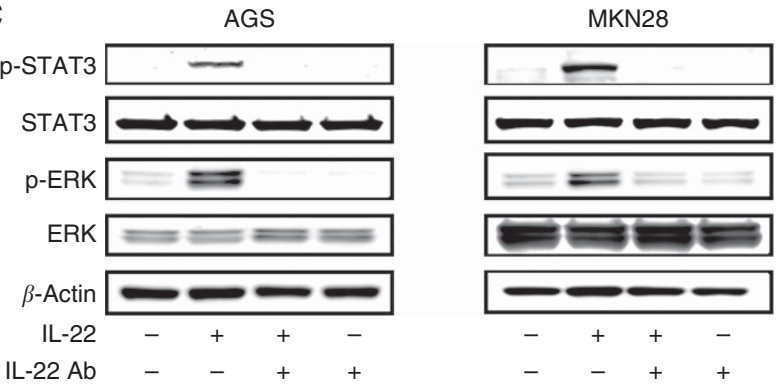

Figure 2. Effect of IL-22 treatment on intracellular signalling in gastric cancer cells. (A) Phosphorylation of STAT3, ERK and Akt in AGS and MKN28 cells treated with IL-22. (B) Expression of p50 and p60 in AGS and MKN28 cells treated with IL-22. AGS cells $\left(1 \times 10^{6}\right)$ and MKN28 cells $\left(1 \times 10^{6}\right)$ were cultured in $6-\mathrm{cm}$ dishes, treated with IL-22 $\left(10 \mathrm{ng} \mathrm{ml}^{-1}\right)$ for the indicated time, and extracted protein was analysed using western blotting. (C) Effect of anti-IL-22 antibody on IL-22-induced STAT3 and ERK phosphorylation in AGS and MKN28 cells. AGS and MKN28 cells were pretreated with IL-22 antibody $\left(20 \mu \mathrm{g} \mathrm{ml}^{-1}\right)$ for $45 \mathrm{~min}$ and then stimulated with IL-22 (10 $\left.\mathrm{ng} \mathrm{ml}^{-1}\right)$ for $30 \mathrm{~min}$.

significantly enhanced dose-dependently by IL-22 stimulation (Figure 3A). Then, to inhibit the effect of IL-22, AGS cells were treated concomitantly with anti-IL-22 antibody $\left(10-40 \mu \mathrm{g} \mathrm{ml}^{-1}\right)$. This abolished the increase in the number of invasive AGS cells stimulated with IL-22 (Figure 3B), and similar findings were also obtained for MKN28 cells (Figure 3C). Moreover, we examined whether IL-22 upregulates the expression of MMP7 and MMP13, which are likely to promote cell invasion in the downstream of IL22 signalling (Howlett et al, 2005; Fukuda et al, 2011). As shown in Figure 3D, IL-22 stimulation enhanced the expression of MMP7 and MMP13 in MKN28 and AGS cells, respectively. In contrast, we showed that the increase of MMP7 and MMP13 expression was abolished by the addition of anti-IL-22 antibody. Regarding the effect of IL-22 on cell proliferation and survival, IL-22 treatment did not show any promoting effects for those cell lines under this experimental condition (Supplementary Figure 2).

Interleukin-22 stimulation promotes gastric cancer cell invasion via STAT3 and ERK signalling. Inhibition of STAT3 signalling by STAT3 siRNA significantly decreased the number of invasive AGS cells accelerated by IL-22 stimulation, showing that IL-22 promotes AGS cell invasion via STAT3 signalling. In addition, STAT3 siRNA significantly inhibited the invasive ability of AGS cells under unstimulated conditions, suggesting that STAT3 signalling is crucial for AGS cell invasion (Figure 4A). 
A

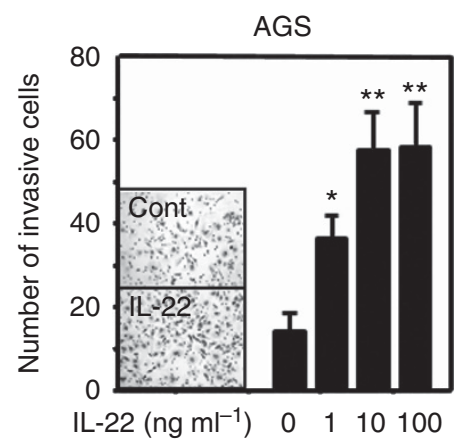

B

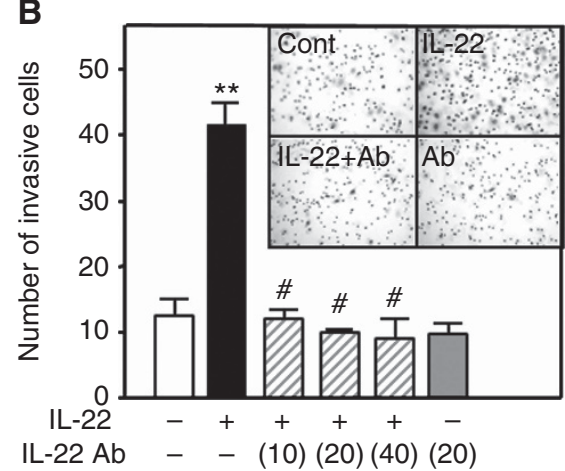

D

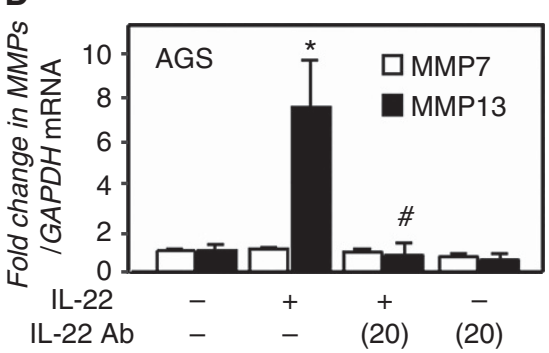

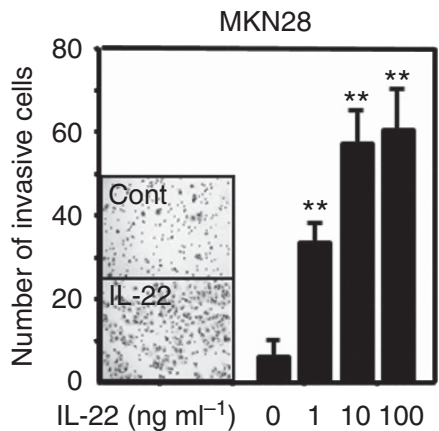

C
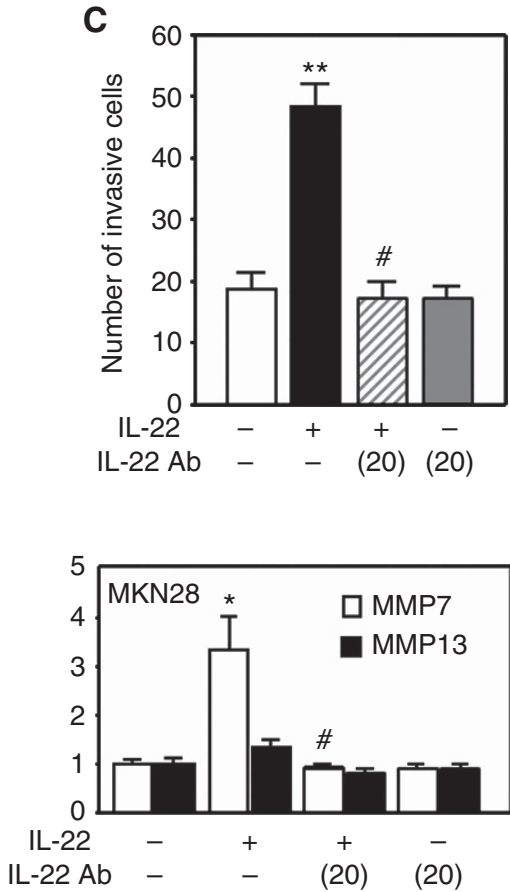

Figure 3. Effect of IL-22 on the invasive potential of gastric cancer cells. (A) Changes in the number of invasive AGS and MKN28 cells under IL-22 stimulation. A representative image showing that IL-22 stimulation promotes AGS and MKN28 cell invasion. Effect of anti-IL-22 antibody on IL-22 (10 $\mathrm{ng} \mathrm{ml}^{-1}$ )-induced invasion of AGS (B) and MKN28 cells (C). A representative image showing control AGS cells, IL-22-treated (10 ng ml ${ }^{-1}$ ) cells, IL-22-treated $\left(10 \mathrm{ng} \mathrm{ml}^{-1}\right)$ cells in the presence of anti-IL-22 antibody $\left(10 \mu \mathrm{g} \mathrm{ml}^{-1}\right)$ and cells cultured with anti-IL-22 antibody alone. (D) Effect of IL-22 on MMP7 and MMP13 expression in gastric cancer cells. All the results are presented as the mean \pm s.e.m. of four independent experiments. Significantly greater than control: ${ }^{\star} P<0.05$, ${ }^{\star \star} P<0.01$. Significantly lower than the IL-22-treated group: ${ }^{\#} P<0.01$.

With regard to MKN28 cells, STAT3 siRNA partly but not completely decreased the number of invasive cells accelerated by IL-22 stimulation, suggesting that not only STAT3 but also some other forms of signalling may mediate the promotion of MKN28 cell invasion by IL-22 (Figure 4B). We furthermore examined whether MAPK signalling is involved in the promotion of gasric cancer cell invasion by IL-22. The increase in the number of invasive AGS cells after the treatment with IL-22 was partly attenuated by concomintant administration of the MEK inhibitor PD98059 (Figure 4C). On the other hand, the increase in the number of MKN28 cells after treatment with IL-22 was reduced to a level equivalent to that in the absebce of stimulation upon treatment with PD98059 (Figure 4D). Throughout the invasion assay, cell viability was $>86 \%$ by trypan blue (data not shown). These findings suggest that IL-22 may promote gastric cancer cell invasion via STAT3 and MAPK signalling, although the predominant intracellular signalling mechanism may differ according to the cell line.

CAF cells promote gastric cancer cell invasion. We examined whether CAF cells produce IL-22 protein by ELISA. The concentration of IL-22 in culture supernatant was lower than the serum concentration from UC, whereas it was higher than the serum concentration from healthy control (Figure 5A). This finding suggests that CAF cells are at least possible to produce IL22 protein. Moreover, we demonstrated that the level of $I L-22$ expression was significantly greater in CAFs than in NGF cells (Figure 5B).

To establish an in vitro model for the invasive front of gastric cancer tissues, we prepared co-culture system using CAF1 and AGS cells. The number of invasive AGS cells was significantly increased when AGS cells were co-cultured with CAF1 cells (Figure 5C). Furthermore, addition of IL-22 antibody abolished the increase in number of invasive AGS cells under co-culture with CAF1 cells (Figure 5C).

\section{DISCUSSION}

Although IL-22 has recently been highlighted in the pathophysiology of inflammatory diseases, its biological role in carcinogenesis is poorly understood. In the present study, we first confirmed that 

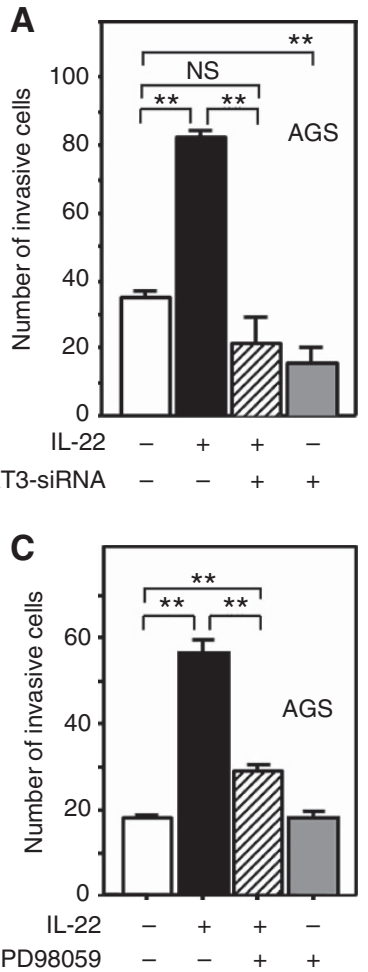

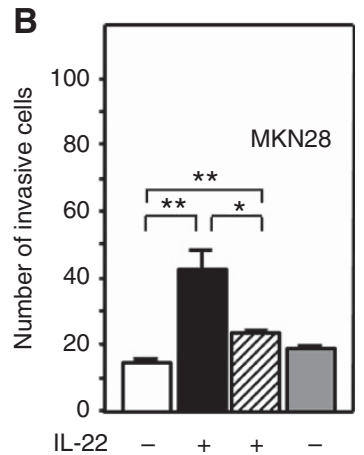

STAT3-SIRNA - -++

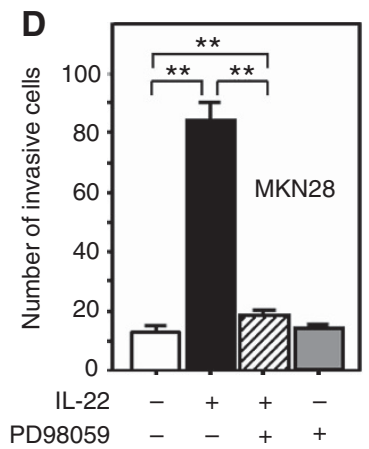

Figure 4. Effect of STAT3 siRNA treatment (A and $\mathbf{B}$ ) and MEK inhibitor ( $\mathbf{B}$ and $\mathbf{D}$ ) on the IL-22-induced invasive potential of gastric cancer cells. AGS and MKN28 cells were transfected with STAT3 siRNA (or non-silencing siRNA as a control) for $48 \mathrm{~h}$ and used for invasion assay $(\mathbf{A}$ and $\mathbf{B})$. The transfected AGS $\left(5 \times 10^{4}\right)$ and MKN28 $\left(5 \times 10^{5}\right)$ were seeded in the upper invasion chamber, stimulated by IL-22 $\left(10 \mathrm{ng} \mathrm{ml}^{-1}\right)$ for $36 \mathrm{~h}$, and evaluated as described in Materials and Methods. Similarly, AGS and MKN28 cells were cultured in the medium with or without PD98059 $(20 \mu \mathrm{M})$ in the upper invasion chamber and stimulated by IL-22 $\left(10 \mathrm{ng} \mathrm{ml}^{-1} ; \mathbf{C}\right.$ and $\left.\mathbf{D}\right)$. All the results are presented as the mean \pm s.e.m. of four independent experiments. Significantly different between two groups: ${ }^{\star} P<0.05,{ }^{\star \star} P<0.01$.

gastric cancer cells bear receptors for IL-22 in vitro and furthermore, using immunohistochemistry, we showed that human gastric cancer lesions indeed express IL-22 receptors, suggesting that gastric cancer cells may be reactive to IL-22 stimulation. We next investigated the expression of IL-22 in human gastric cancer tissues because little information is available about the clinicopathological significance of IL-22 expression in any human cancerous tissues. Interestingly, we observed strong expression of IL-22 in stromal cells at the invasive front of the tumour, suggesting that IL-22 signalling may be involved in gastric cancer cell invasion. In support of this hypothesis, gastric cancers that have IL-22-positive stromal cells at the invasive front showed not only a significantly high risk of lymphatic invasion but also a high tumour stage although this must be reconfirmed in a larger study including more number of gastric cancers without lymphatic invasion.

To clarify whether IL-22 promotes the invasion ability of gastric cancer cells, we stimulated two gastric cancer cell lines with IL-22 in an in vitro invasion assay. As shown in Figure 3, IL-22 stimulation significantly promoted the invasive ability of gastric cancer cells, and its effect was abolished by addition of IL-22 antibody, confirming that IL-22 is an invasion-promoting factor for gastric cancer cells. Although we did not test the effect of IL-22 in in vivo models, it is noteworthy that hepatocellular carcinoma co-transplanted with IL-22-expressing lymphocytes showed a high potential for invasion and metastasis (Jiang et al, 2011). Gastric cancer cells are known to have higher invasion and metastasis
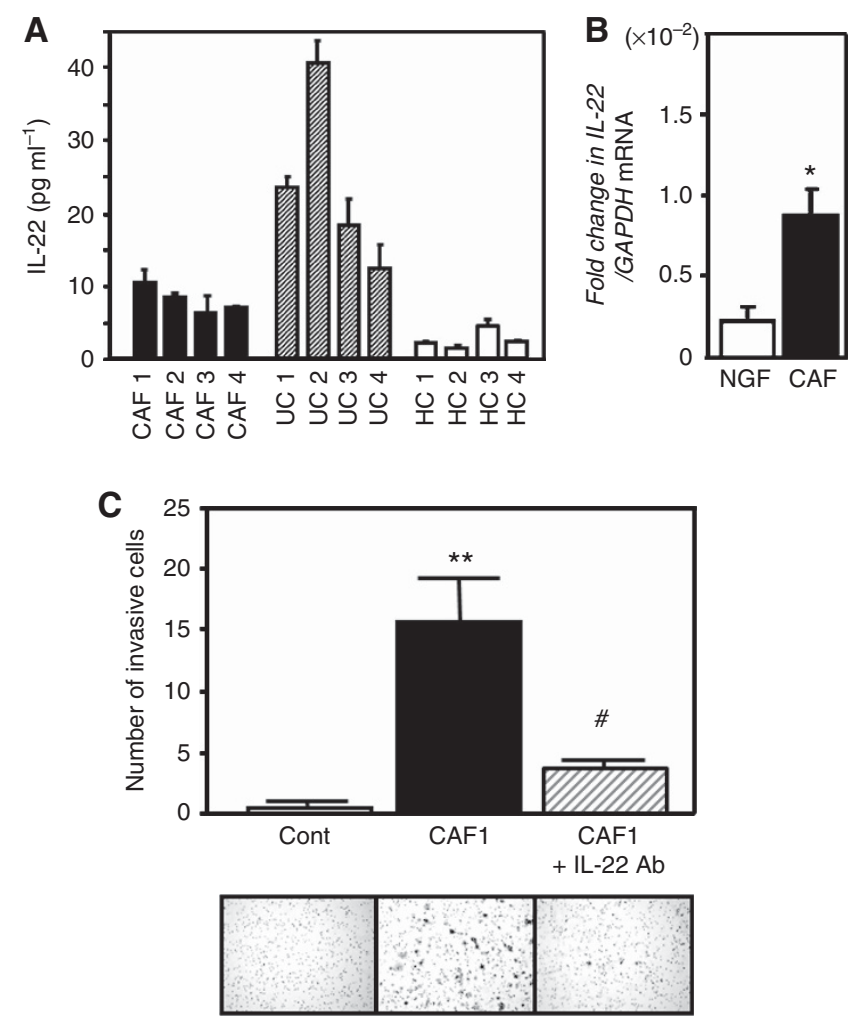

Figure 5. CAF cells promote AGS cell invasion via IL-22. (A) IL-22 production from CAF cells. CAF culture supernatant and serum from healthy control $(\mathrm{HC})$ and $U C$ patients were analysed by ELISA.

(B) Expression of IL-22 in NGF and CAF cells $(n=4)$. (C) Effect of IL-22 on the link between CAF and AGS cells $(n=4)$. CAF1 $\left(1 \times 10^{5}\right)$ cells were cultured in the lower chamber for $24 \mathrm{~h}$. After washing with serumfree medium, upper invasion chambers were placed above the lower chambers and AGS cells $\left(5 \times 10^{4}\right)$ were then placed there in serum-free medium with or without anti-IL-22 antibody $\left(10 \mu \mathrm{g} \mathrm{ml}^{-1}\right)$. After an additional $30 \mathrm{~h}$ of co-culture, the number of invaded AGS cells was evaluated as described in Materials and Methods. Photographs showing invasive gastric cancer cells in each group. All the results are presented as the mean \pm s.e.m. Significantly greater than the control group: ${ }^{\star} P<0.05,{ }^{\star \star} P<0.01$. Significantly lower than the CAF1 co-cultured group: ${ }^{\#} P<0.01$.

potential than other solid tumours. Therefore, IL-22 warrants further study as a potentially important mediator of invasion/ metastasis in gastric carcinogenesis.

Previous studies have indicated that IL-22 may activate various pathways such as STAT3, MAPK, Akt and/or NF- $\kappa$ B signalling in different types of cells (Lejeune et al, 2002; Andoh et al, 2005; Zhang et al, 2008). In this regard, we examined the signalling pathways activated by IL-22 in human gastric cancer cells and subsequently showed that STAT3 and ERK phosphorylation was enhanced in two of the gastric cancer cell lines examined. Accumulating evidence suggests that IL-22 is possible to promote cell proliferation and anti-apoptosis via STAT3 and/or ERK signalling (Brand et al, 2006; Ziesché et al, 2007; Zhang et al, 2008; Sekikawa et al, 2010; Jiang et al, 2011). In addition, we have clarified in the present study that IL-22 significantly promoted the invasive ability of two gastric cancer cell lines via STAT3 and ERK signalling. These effects of IL-22 seem to be advantageous to tumour progression, and indeed, recent studies has reported that IL-22 is associated with tumour progression and prognosis in human malignancies (Kobold et al, 2013; Wen et al, 2014).

Interleukin-22 is normally expressed in immune cells such as IL-17-producing $\mathrm{T}$ (Th17), NK, dendritic, and lymphoid 
tissue-inducer cells (Zenewicz and Flavell, 2011). However, it was noteworthy that IL-22 was strongly expressed in $\alpha$ SMA-positive fibroblasts neighbouring gastric cancer cells at the invasive front. The fibroblasts in such a tumour microenvironment are referred to as CAF cells and can be detected by their $\alpha$ SMA expression (Xing et al, 2010; Cirri and Chiarugi, 2012). In this context, it is tempting to speculate that IL-22 is produced in CAF cells in gastric cancer tissues. In support of this, we confirmed that IL-22 is expressed in isolated CAF cells from gastric cancer tissues. Although we are unable to explain why IL-22 is expressed in CAF cells, recent evidence has suggested that CAF cells originate from not only resident fibroblasts but also bone marrow-derived progenitors or transformed cells from endothelial or cancer cells (Xing et al, 2010; Cirri and Chiarugi, 2012). Thus, the heterogeneity of CAF cells may explain the unexpected expression of IL-22 in CAF cells.

CAF cells have recently received attention because of their pivotal roles in tumour growth, angiogenesis, invasion, and metastasis by interacting with tumour cells (Bhowmick et al, 2004; Xing et al, 2010; Cirri and Chiarugi, 2012). Although the mechanism of the interaction between CAF and tumour cells is not fully understood, growth factors, chemokines or extracellular matrix are thought to be important mediators by which such cells communicate with their microenvironment (Bhowmick et al, 2004; Xing et al, 2010; Cirri and Chiarugi, 2012). Regarding the role of IL-22 in cancerous cells, a few studies have indicated that IL-22 can function as a cell growth and/or anti-apoptotic factor in vitro (Brand et al, 2006; Zhang et al, 2008; Jiang et al, 2011), although the source of IL-22 in human cancerous tissues has remained unclear. In this context, we have shown for the first time that IL-22 promotes the invasive ability of gastric cancer cells via STAT3 and ERK activation, and that CAF is a possible source of IL-22 at the invasive tumour front. Although these two important findings were confirmed in different series of experiments, our co-culture experiment lent further support to the possibility that IL-22expressing CAFs actually have a role in the promotion of gastric cancer cell invasion.

In summary, we have clarified that IL-22 promotes the invasive ability of gastric cancer cells via STAT3 and ERK activation. Moreover, we have shown that IL-22 is expressed in CAFs at the invasive front of gastric cancer lesions and that IL-22-expressing CAFs isolated from human gastric cancer promote invasion of the cancer cells. Together, these results suggest that IL-22 produced by CAFs promotes gastric cancer cell invasion via STAT3 and ERK signalling.

\section{ACKNOWLEDGEMENTS}

This work was supported in part by Grants-in-aid for Scientific Research 23590929 from the Ministry of Education, Culture, Sports, Science and Technology, Japan. We thank Noriko Kamiya and Mayumi Yamada (Hyogo College of Medicine) for their technical assistance. We also thank Chiaki Matsuyama and Ayako Shimizu (Dokkyo University School of Medicine) for their technical assistance.

\section{CONFLICT OF INTEREST}

The authors declare no conflict of interest.

\section{REFERENCES}

Aggarwal S, Xie MH, Maruoka M, Foster J, Gurney AL (2001) Acinar cells of the pancreas are a target of interleukin-22. J Interferon Cytokine Res 21: 1047-1053.
Andoh A, Zhang Z, Inatomi O, Fujino S, Deguchi Y, Araki Y, Tsujikawa T, Kitoh K, Kim-Mitsuyama S, Takayanagi A, Shimizu N, Fujiyama Y (2005) Interleukin-22, a member of the IL-10 subfamily, induces inflammatory responses in colonic subepithelial myofibroblasts. Gastroenterology 129: 969-984.

Bhowmick NA, Neilson EG, Moses HL (2004) Stromal fibroblasts in cancer initiation and progression. Nature 432: 332-337.

Brand S, Beigel F, Olszak T, Zitzmann K, Eichhorst ST, Otte JM, Diepolder H, Marquardt A, Jagla W, Popp A, Leclair S, Herrmann K, Seiderer J,

Ochsenkühn T, Göke B, Auernhammer CJ, Dambacher J (2006) IL-22 is increased in active Crohn's disease and promotes proinflammatory gene expression and intestinal epithelial cell migration. Am J Physiol 290: G827-G838.

Cirri P, Chiarugi P (2012) Cancer-associated-fibroblasts and tumor cells: a diabolic liaison driving cancer progression. Cancer Metastasis Rev 31: 195-208.

Dumoutier L, Louahed J, Renauld JC (2000a) Cloning and characterization of IL-10-related T cell-derived inducible factor (IL-TIF), a novel cytokine structurally related to IL-10 and inducible IL-9. J Immunol 164: 1814-1819.

Dumoutier L, Roost EV, Colau D, Renauld JC (2000b) Human interleukin10-related $\mathrm{T}$ cell-derived inducible factor: molecular cloning and functional characterization as an hapatocyte-stimulating factor. Proc Natl Acad Sci USA 97: 10133-10149.

Fukuda A, Wang SC, Morris JP, Folias AE, Liou A, Kim GE, Akira S, Boucher KM, Firpo MA, Mulvihill SJ, Hebrok M (2011) Stat3 and MMP7 contribute to pancreatic ductal adenocarcinoma initiation and progression. Cancer Cell 19: 441-455.

Fukui H, Sekikawa A, Tanaka H, Fujimori Y, Katake Y, Fujii S, Ichikawa K, Tomita S, Imura J, Chiba T, Fujimori T (2011) DMBT1 is a novel gene induced by IL-22 in ulcerative colitis. Inflamm Bowel Dis 17: $1177-1188$.

Hoshino M, Fukui H, Ono Y, Sekikawa A, Ichikawa K, Tomita S, Imai Y, Imura J, Hiraishi H, Fujimori T (2007) Nuclear expression of phosphorylated EGFR is associated with poor prognosis of patients with esophageal squamous cell carcinoma. Pathobilogy 74: 15-21.

Howlett M, Judd LM, Jenkins B, LA Gruta NL, Grail D, Ernst M, Giraud AS (2005) Differential regulation of gastric tumor growth by cytokines that signal exclusively through the coreceptor gp130. Gastroenterology 129: 1005-1018.

Jiang R, Tan Z, Deng L, Chen Y, Xia Y, Gao Y, Wang X, Sun B (2011) Interleukin-22 promotes human hepatocellular carcinoma by activation of STAT3. Hepatology 54: 900-909.

Kamangar F, Dores GM, Anderson WF (2006) Patterns of cancer incidence, mortality, and prevalence across five continents: defining priorities to reduce cancer disparities in different geographic regions of the world. J Clin Oncol 24: 2137-2150.

Kobold S, Völk S, Clauditz T, Küpper NJ, Minner S, Tufman A, Düwell P, Lindner M, Koch I, Heidegger S, Rothenfuser S, Schnurr M, Huber RM, Wilczak W, Endres S (2013) Interleukin-22 is frequently expressed in small- and large-cell lung cancer and promotes growth in chemotherapyresistant cancer cells. J Thorac Oncol 8: 1032-1042.

Lejeune D, Dumoutier L, Constantinescu S, Kruijer W, Schuringa JJ, Renauld JC (2002) Interleukin-22 (IL-22) activates the JAK/STAT, ERK, JNK, and p38 MAP kinase pathways in a rat hepatoma cell line. J Biol Chem 277: 33676-33682.

Liang SC, Tan XY, Luxenberg DP, Karim R, Dunussi-Joannopoulos K, Collins M, Fouser LA (2006) Interleukin (IL)-22 and IL-17 are coexpressed by Th17 cells and cooperatively enhance expression of antimicrobial peptides. J Exp Med 203: 2271-2279.

Naher L, Kiyoshima T, Kobayashi I, Wada H, Nagata K, Fujiwara H, Ookuma YF, Ozeki S, Nakamura S, Sakai H (2012) STAT3 signal transduction through interleukin-22 in oral squamous cell carcinoma. Int J Oncol 41: 1577-1586.

Ogata H, Sekikawa A, Yamagishi H, Ichikawa K, Tomita S, Imura J, Ito Y, Fujita M, Tsubaki M, Kato H, Fujimori T, Fukui H (2010) GRO $\alpha$ promotes invasion of colorectal cancer cells. Oncol Rep 24: 1479-1486.

Rutz S, Eidenschenk C, Ouyang W (2013) Il-22, not simply a Th17 cytokine. Immunol Rev 252: 116-132.

Sekikawa A, Fukui H, Fujii S, Ichikawa K, Tomita S, Imura J, Chiba T, Fujimori T (2008) REG I $\alpha$ protein mediates an anti-apoptotic effect of STAT3 signaling in gastric cancer cells. Carcinogenesis 29: 76-83. 
Sekikawa A, Fukui H, Suzuki K, Karibe T, Fujii S, Ichikawa K, Tomita S, Imura J, Shiratori K, Chiba T, Fujimori T (2010) Involvement of the IL-22/REG I $\alpha$ axis in ulcerative colitis. Lab Invest 90: 496-505.

Wen Z, Liao Q, Zhao J, Hu Y, You L, Lu Z, Jia C, Wei Y, Zhao Y (2014) High expression of interleukin-22 and its receptor predicts poor prognosis in pancreatic ductal adenocarcinoma. Ann Surg Oncol 21: $125-132$.

Wolk K, Kunz S, Witte E, Friedrich M, Asadullah K, Sabat R (2004) IL-22 increases the innate immunity of tissue. Immunity 21: 241-254.

Xie MH, Aggarwal S, Ho WH, Foster J, Zhang Z, Stinson J, Wood WI, Goddard AD, Gurney AL (2000) Interleukin (IL)-22, a novel human cytokine that signals through the interferon receptor-related proteins CRF2-4 and IL-22R. J Biol Chem 275: 31335-31339.

Xing F, Saidou J, Watabe K (2010) Cancer associated fibroblasts (CAFs) in tumor microenvironment. Front Biosci 15: 166-179.

Zenewicz LA, Flavell RA.. Recent advances in IL-22 biology (2011) Int Immunol 23: 159-163.

Zhang W, Chen Y, Wei H, Zheng C, Sun R, Zhang J, Tian Z (2008) Antiapoptotic activity of autocrine interleukin-22 and therapeutic effects of interleukin-22-small interfering RNA on human lung cancer xenografts. Clin Cancer Res 14: 6432-6439.

Zheng Y, Danilenko DM, Valdez P, Kasman I, Eastham-Anderson J, Wu J, Ouyang W (2007) Interleukin-22, a $\mathrm{T}_{\mathrm{H}} 17$ cytokine, mediates IL-23induced dermal inflammation and acanthosis. Nature 445: 648-651.

Ziesché E, Bachmann M, Kleinert H, Pfeilschifter J, Mühl H (2007) The interleukin-22/STAT3 pathway potentiates expression of inducible nitric-oxide synthase in human colon carcinoma cells. J Biol Chem 282: 16006-16015.

Ziesché E, Scheiermann P, Bachmann M, Sadik CD, Hofstetter C, Zwissler B, Pfeilschifter J, Mühl H (2009) Dexamethasone suppresses interleukin-22 associated with bacterial infection in vitro and in vivo. Clin Exp Immunol 157: $370-376$.

This work is published under the standard license to publish agreement. After 12 months the work will become freely available and the license terms will switch to a Creative Commons AttributionNonCommercial-Share Alike 3.0 Unported License.

Supplementary Information accompanies this paper on British Journal of Cancer website (http://www.nature.com/bjc) 